\title{
The Strategic Use of Resettlement: Changing the Face of Protection?
}

\author{
JoAnNe VAn SELM
}

\begin{abstract}
Discussion about resettlement is increasing worldwide. Traditional resettlement countries look to the EU to establish new programs to expand the use of this durable solution. Some EU Member States appear most interested in resettlement for the potential it might offer in resolving the problems of smuggling, high asylum-seeker arrivals, and widespread anti-immigrant tendencies. This article sets out four key arguments on: the reasons for conducting resettlement; the "see-saw" numbers hypothesis; perceptions of refugees according to their means of arrival; and the links between asylum and resettlement, while discussing the European developments and global discussion of the strategic use of resettlement.
\end{abstract}

\section{Résumé}

La réinstallation devient de plus en plus un sujet de préoccupation au niveau international. Les pays de réinstallation traditionnels se tournent vers l'Union Européenne et s'attendent à ce qu'elle développe de nouveaux programmes pour étendre l'usage de cette solution durable. Certains pays de l'UE semblent extrêmement intéressés dans la réinstallation en vue du potentiel qu'elle offre pour résoudre les problèmes de passages clandestins de personnes, de hauts niveaux d'arrivée de demandeurs d'asile et des tendances généralisées anti-immigrants. Cet article met de l'avant quatre arguments principaux: les raisons d'avoir une politique de réinstallation; l'hypothèse des nombres en balançoire à bascule; la perception variable qu'on a des réfugiés selon leur mode d'arrivée; et, les liens entre le droit d'asile et la réinstallation - tout en discutant des développements européens et des pourparlers globaux sur l'utilisation stratégique de la réinstallation.

\section{Introduction}

"Resettlement" has become one of the most frequently heard words in refugee protection policy discussions in the developed world. After decades as a barely-spoken-of means by which some refugees reached western states, the approach is centre stage. To countries that have long-standing resettlement programs there are aspects of this re-emergence that must be bemusing, aspects that pose challenges to their own programs, and aspects which are encouraging for the future of a protection tool and durable solution which has served them and refugees well. The existing resettlement countries inspired the discussion: their initiative coincided with new European interest in resettlement as an approach to refugee protection.

While wanting to see other states get involved and take on part of the resettlement caseload, traditional resettlement countries are also concerned that resettlement should be well managed by all actors involved for the benefit of all. Within the framework of the Convention Plus and Forum, launched in 2002 and 2003 respectively by UN High Commissioner for Refugees, Ruud Lubbers, the "Strategic Use of Resettlement" has become the foremost subject of discussion. Further, both the U.S. and the EU have sought independent studies in the past year, assisting policy makers and political leaders in thinking about changes in, or the development of, resettlement programs. ${ }^{1}$

The European Union is starting to think about resettlement and how it could be used strategically. The developments which have led to this discussion included the challenges posed by human smuggling, over-burdened asylum systems in which some 50 per cent of the applicants were being rejected by the end of all appeals process, and an increasingly pervasive tide of anti-immigrant sentiment. By the time a significant number of the EU Member States had engaged the discussion in 2003, the United States was 
facing significant challenges to its long cherished and wellestablished resettlement program. Those challenges were highlighted by heightened security concerns in the aftermath of $9 / 11$, but in fact started earlier. The program had become somewhat anachronistic. It was well suited to the Cold War, but ten years after the collapse of the Berlin Wall it had not significantly changed in terms of groups targeted. In changing priorities on groups eligible for selection, the program also needed to adapt its methods.

In the final paragraphs of this Introduction the four key points or arguments to be made in the article will be set out. The following section will explain "resettlement" as a concept and a protection tool in more detail. After posing questions about who could benefit - and how - from the strategic use of resettlement, the focus will be on Europe and on the "global" level discussions about resettlement of the past few years. The challenges to resettlement, as well as the opportunities which resettlement appears to some policy makers to offer, will permeate the rest of this article.

\section{Key Points}

1. There is a risk in discussing the "strategic use" of resettlement that motives, goals, and functions of the policy approach become confused and conflated in such a way that the essence of resettlement as a humanitarian program could be lost. This is a serious challenge not only to resettlement itself, but to refugee protection policies in developed countries generally - and a challenge which needs to be addressed.

2. While attention is on resettlement there may be room to deal with the difficulties presented by asylum and irregular entries, in a climate which is more beneficial to good policy making and supportive of refugees than that which prevails today. This is already evident in both Canada and the U.S. This is an opportunity. There lies potential danger, however, in the use states could make of resettlement as a "humanitarian alibi" for restrictive asylum policies. This is demonstrated to an extent in Australia, where asylum seekers are sometimes characterized as "queue jumpers," i.e., people who should have waited for the resettlement program to find them, if indeed they are refugees. The notion underlying the use of the alibi is that people who wait in camps are deserving of compassion and protection, whereas those who take the initiative, even if they are from the same population group as those later resettled, might be vilified. Ironically, we could hypothesize that asylum seekers are in fact showing the type of resourcefulness that would qualify them as those who will succeed in western societies and economies. Nonetheless, in Europe, some focus on positive aspects to refugee admissions could be used effectively to change the debate which currently casts all irregular arrivals as asylum seekers, and describes them all - whether determined to be refugees or not - as scroungers on the welfare states of European countries.

3. Any discussion on the strategic use of resettlement that is based on a see-saw hypothesis in regard to arrival numbers is not only refutable, but also dangerous to the desirable establishment of broad resettlement programs on a global level. The see-saw hypothesis suggests that, whereas in Europe today there are significant asylum-seeker arrivals and is very little resettlement, if in the future there were to be significant resettlement, there would be a decrease in asylum-seeker arrivals. This hypothesis is mostly being employed in the EU discussions; but it is being broadly employed by officials (from Europe and beyond), NGOs, and others in an attempt to "sell" resettlement as an effective protection tool. That resettlement is an effective protection tool is not at issue here; but "selling" the policy to politicians and the general public, as a tool for effectively reducing asylum-seeker arrival numbers, is a great risk. The risk is that a very good resettlement program, which is very effective in broadening access to refugee protection, might be undermined if it were to be evaluated on the basis of its impact on asylum-seeker arrival numbers.

4. Resettlement is not asylum, or part of an asylum system. Rather, both asylum and resettlement are elements in a broad, well-functioning and robust international protection system.

\section{What Is Resettlement?}

Although the word "resettlement" is much used, not everyone knows what it is - or means the same thing when they use the term. ${ }^{2}$ In this article, and in the broadest policy sense, resettlement involves the selection and transfer of refugees from a state in which they have initially sought protection to a third state which has agreed to admit them with permanent residence status. Resettlement can be used when refugees can neither return to their country of origin, nor be protected effectively and integrate in their country of first asylum. There are three traditional and equal goals of resettlement: protection, provision of durable solutions, and burden sharing with host countries.

Asylum is a much better known tool of refugee protection in the developed world, especially in Europe, so it is useful to describe resettlement in comparison to asylum. Both resettlement and asylum can offer humanitarian protection and may form complementary elements in an overall refugee protection framework. However, the starting points of the processes are different. Resettlement is a program through which states decide in advance who they can help and select individuals whose protection they can guarantee after arrival. Resettlement can offer a durable solution in protracted refugee situations and can be a tool for the 
managed arrival of refugees whose status is determined in advance of their travel. Domestic asylum systems, in contrast, should be maintained for people who have sought and requested, by their own means, the protection of a safe and rights-respecting state. Furthermore, asylum is anchored firmly in international and domestic law, and carries legal obligations, particularly in the area of non-refoulement. Resettlement may be governed by some domestic legal statutes, but is a discretionary act, and is often based more in policy than in law, even if admission through a resettlement program conveys legal rights to residence to the individuals selected.

Resettlement is a much more complex process than initially seems to be the case. It is resource intensive. It is worth doing well, because resettlement is both about giving refugees the opportunity to get their lives back and about reflecting the humanitarian values of receiving societies. The "right reasons" for doing resettlement include the traditional goals of offering protection, a durable solution, and burden sharing; but these goals can be put into effect by using resettlement to achieve both its humanitarian motives and some more utilitarian ends. Hence, UNHCR and the resettlement countries are engaged in discussion about the strategic use of resettlement in the context of the Convention Plus Forum.

\subsection{Which Countries Resettle?}

Eighteen countries have resettlement programs. ${ }^{3}$ Four of them do not have operating programs as such; they are either under review by UNHCR or have been suspended from the list of "emerging resettlement countries." However, others are thinking of joining them. If one includes all eighteen countries listed below, in spite of the caveats about their operation, there has been a doubling of resettlement countries over a period of some seven years. The eighteen programs, in order of magnitude of permitted annual admissions, are run by: United States, Canada, Australia, Sweden, Norway, Finland, New Zealand, Denmark, Netherlands, UK, ${ }^{4}$ Ireland, Brazil, Chile, Iceland, Argentina, ${ }^{5}$ Benin, ${ }^{6}$ Burkina Faso, and Spain. ${ }^{7}$

The U.S. has had an annual ceiling ${ }^{8}$ of between 70,000 and 132,000 refugees each year over the past decade, and a total admission of 807,008 refugees through resettlement between 1993 and 2002. Canada has a target of some 12,000 refugees for resettlement across three types of resettlement program. Australia aims to receive 12,000 refugees per year, with precise resettlement numbers dependent on the number of asylum applications receiving a positive determination and thereby qualifying them as among the 12,000. Over the three fiscal years 2001-2003, Australia resettled 28,106 people and granted asylum to $10,437 .{ }^{9}$ In the EU,
Sweden has a quota for 1,000 resettlement places, Finland for 750, Denmark, the Netherlands and the UK have 500person programs, and Ireland has a 10-case program, which could receive up to 60 people in total (in family groups which each form one case).

In preparation for the discussion below, it is worth noting that the U.S. has also has received 822,224 asylum applications between 1993 and 2002. Canada currently receives between 30,000 and 40,000 asylum applications annually. Australia's asylum-seeker arrival numbers fluctuate. The country received just over 12,366 applications in 2001 and just over 6,000 in 2002. All EU member states which resettle receive many more asylum applications than they have resettlement places $^{10}$ - and all experience the fluctuations in asylum statistics over the years that are common in the EU. No country that carries out resettlement in significant numbers has seen spontaneous arrivals of asylum-seekers disappear or dwindle as a result of resettlement. None of these countries has engaged in resettlement with the goal of offering an alternative route to the smuggling and asylum-seeking path.

\subsection{How Does Resettlement Work?}

Selection for resettlement is not as easy as saying, "Well, there are 20 million refugees, so let's resettle 100,000 of them." The process requires criteria to establish which of those refugees need resettlement (who cannot return, and are unable to integrate locally) and who among them might "fit" well with the domestic and foreign policy agendas of the receiving government. These agendas may have little impact on resettlement policies - it might be a matter of giving the destination state a humanitarian profile through the resettlement of the very vulnerable, for example. But the larger the resettlement program, the more various interests and needs must be addressed.

The U.S. has the most sophisticated resettlement system, with three active priority categories for selection. These are: (1) those referred by UNHCR; (2) those falling within designated groups of ethnic origin and/or country of first asylum; and (3) family members of people already in the U.S. from specified countries and who are refugees.

For all three categories, the refugee definition of the Protocol applies, modified to say that they should be outside the United States, rather than outside their country of origin. The second category is the most-used route. Its groups are designated annually, through consultation by the State Department with other government departments, UNHCR, and NGOs. The individuals to be resettled within these groups have assistance in preparing their cases from NGOs. UNHCR's role is limited to consultation during the group designation process. UNHCR has no central role in 
the third category either. However, its role is key to the first priority. Until 2003 these referrals were only of individuals; in 2003, in an effort to fill a significant shortfall in U.S. arrivals, an agreement was reached for UNHCR to refer a group - some 7,000 refugees in Cote d'Ivoire. As is usually the case, the paperwork for all of these refugees was to be completed by a contracted NGO acting as an Overseas Processing Entity, prior to U.S. Immigration Service interviews with the candidates. Nonetheless, as always, the U.S. would not necessarily accept all UNHCR referrals: it is possible that the Immigration Service staff do not find a given individual to be a refugee according to their definition, especially as UNHCR employs its Mandate definition, which covers those fleeing conflict, for example. Indeed, the U.S. is striving to accept 50 per cent of UNHCR referrals, a clear indication that more than half have been rejected in recent years.

Since 2002, Canada has moved to limit applications for resettlement made directly by refugees to Canadian embassies, and has placed a much greater emphasis on referrals, chiefly from UNHCR. The Immigration and Refugee Protection Regulations of June 11, 2002, (section 150), require that applications for refugee resettlement be accompanied by a referral from a "referral organization" or from a private sponsor. Section 143 of the Regulations clarifies that "referral organization" means UNHCR or another organization with which the Department of Citizenship and Immigration has concluded a Memorandum of Understanding. Canada relies currently on UNHCR referrals and private sponsors to identify refugees for resettlement, and has not yet concluded agreements with any NGOs or other agencies.

The EU Member States with resettlement programs, and Norway, rely exclusively on UNHCR referrals for selection. The process is cumbersome, and some, most especially the Netherlands, also refuse some 50 per cent of the referred cases on the grounds that their Immigration Service finds the candidates not to be refugees according to the Dutch Aliens Act.

UNHCR is currently charged with referring some 50,000 refugees per year worldwide to all programs, including the U.S. and Canada. With relatively high rejection rates in some states, based not only on definitional differences but also, for the Europeans, on what they view as incomplete information on the referral forms, UNHCR is putting a lot of resources into resettlement. For the Europeans this includes a whole system of clarifying claims and funnelling referrals from the field through Geneva headquarters to the capitals (the U.S. and Canada receive referrals directly in the field, including through a new "hub" system in west and east Africa). All in all, it is resource intensive, and not clear that UNHCR either can or should be performing some of the functions, beyond identifying people as refugees. In spite of the apparent faith placed in the agency in the current European and Canadian systems, and the rhetoric about UNHCR's role in new resettlement programs, the high rejection rate shows there is not much trust among resettlement countries that UNHCR really knows who is a refugee.

\section{What Might Be Strategic about Doing Resettlement: For Whom, and Why?}

One of the goals of resettlement is solidarity with countries of first asylum. The experiences of Southeast Asian countries in the 1970s and 1980s demonstrate this. Thailand and Malaysia were persuaded to offer initial protection to hundreds of thousands of refugees from Vietnam only because they were assured that countries in North America and Australia as well as several European states would resettle the refugees. Austria was likewise in a position to receive and temporarily offer refuge to many thousands of refugees from Hungary in 1956, because other states were willing to organize their onward movement and protection. While solidarity is a traditional goal of resettlement, the implementation of the policy in search of this goal can also prove to be strategic. It can provide a way in which resettlement can serve a foreign policy function, while achieving a principled aim. Resettlement can be strategically used to support countries of first asylum, encouraging them to continue to offer at least shortterm effective protection when major crises occur in neighbouring states.

Another goal of resettlement is to offer a durable solution to refugees who are in a protracted situation in which their short-term protection in a country close to home may have been effective, but they can neither return, nor reasonably stay in that country of first asylum for a long time. By offering a durable solution where resettlement is the only solution possible for an individual or group of refugees, resettlement countries can meet the protection needs of the refugees concerned, and can offer those refugees an opportunity for durable, effective protection, without the need to take personal risks to achieve that.

These applications of resettlement show how it can be effectively used as one of three durable solutions in a comprehensive approach, to the benefit of refugees and several states. Resettlement can also serve foreign and domestic policy agendas through resettlement criteria which respond to interest groups, as outlined above.

One myth about resettlement is the idea that states use resettlement for economic immigration purposes. Across Europe there are policy makers, practitioners, and academics who imagine the U.S., Canada, and Australia sending their officials into the world to find the most intelligent refugees in order to resettle them. Only one of these coun- 
tries, Canada, uses "an expectation of self-sufficiency within three years" as a criterion in resettlement selection. Canada does not apply this criterion to vulnerable cases. In other cases it is applied chiefly through the instinct of the selecting officer; such an expectation is not measurable, and, anyway, it simply means having employment and not depending on welfare benefits. Any job will do: it is not a question of looking for the brightest or fittest. One only has to look at the groups that have been resettled in recent years to see that the notion of choosing the brightest and most likely to succeed is a total myth. That is not to say that the refugees resettled to the U.S., Canada, and Australia do not succeed - very many of them do. However, that success can be put down to policies that impact the refugees after selection for resettlement and not to criteria for selecting them in the first place.

The emerging thought in Europe is that if a country resettles refugees, as opposed to seeing them arrive spontaneously, the authorities know who they are, the people enter legally, and the process can be managed. To the extent that this can be true for those who are resettled, this thinking is correct: where it fails is in the implicit notion that because resettlement is conducted, there would not be spontaneous arrivals. It is ironic that as the EU sees opportunities to manage arrivals and have more information about the individuals arriving in advance, the U.S. is precisely seeing challenges to its resettlement program in the context of security concerns. On the one hand the State Department has concerns about US government personnel travelling to certain locations for resettlement selection interviews. On the other hand, Immigration officials certainly do not want to admit someone who turns out to be a terrorist in waiting. While the program has never previously been abused in this way, and is unlikely to see such abuse given the protracted camp life from which most resettlement candidates are drawn, it is a concern which since 9/11 seems to be bringing the program down. However, the U.S. has always used its resettlement program for foreign policy purposes, with the State Department as a driving force, while in the EU the push to consider resettlement is coming from Justice ministries and not Foreign Affairs.

\section{The European Context}

The discussion about appropriate ways to permit refugees to arrive lawfully in EU Member States is taking place outside the context of the work program set out in the Treaty of Amsterdam. A link to the work program is being made by the suggestion that resettlement has something to do with relations between the $\mathrm{EU}$ and countries in the regions of origin of refugees; however, such an international relations perspective to resettlement is not part of the experience of the traditional resettlement countries. Refugee resettlement is being considered more widely both in individual governments $^{11}$ and in the European Commission, as a way of managing the arrival of pre-selected refugees.

In the debate about resettlement in Europe, the role it can play in managing refugees' arrival in an orderly fashion has become prominent, and is seen as one facet of the potential strategic use of this protection tool. In the Conclusions to the Thessaloniki Summit in June 2003, the European Council took note of:

...the Communication from the Commission, which is focusing on more accessible, equitable and managed asylum systems, and invite[d] the Commission to explore all parameters in order to ensure more orderly and managed entry in the EU of persons in need of international protection, and to examine ways and means to enhance the protection capacity of regions of origin with a view to presenting to the Council, before June 2004 a comprehensive report suggesting measures to be taken, including legal implications.

The Communication from the Commission referred to above was in part a response to proposals tabled by the UK in February 2003. ${ }^{12}$ The British government had proposed that transit processing zones be established in places distant from the EU, in which asylum applicants would be processed and, if determined to be in need of protection, moved on at some point to the EU. This proposal was later dropped, as there was little or no interest in it from other Member States. A further proposal, to look at protection in regions of origin, including capacity building for states in those regions, is still under investigation and the subject of pilot projects run by a small group of states including Denmark and the Netherlands. However, several Member States, including the Greek Presidency, and the two major traditional resettlement countries in the EU, Sweden and Finland, raised objections to the pursuit of the UK proposals. In the earliest iterations by the UK, these proposals included the notion that some people might be removed from the regions of origin if their longterm situation proved unstable. This was termed "resettlement" but little resembled traditional understandings of the concept. Concepts change over time, of course, but attaching resettlement to a duty for refugees to remain in their region of origin in the first instance would be a fundamental shift in thinking. Resettlement has long been attached to support for first asylum in regions of origin - but that is rather as an inducement to states in the regions to remain open to refugees, and not a constraint on those refugees' onward movement should they choose to seek asylum spontaneously further afield.

There seems to be a split between EU Member States on what the motives for resettlement are and what functions it 
might allow the states to fulfill. Some governments appear to see assistance in resolving the asylum crisis as a motive for resettlement, whereas others see that as a potential function for this policy approach, which they maintain should be pursued for only humanitarian motives. This analysis of the divergence of opinion speaks to the first key point set out in the Introduction. It also raises questions about how strategically the discussion on whether or not to conduct resettlement is being managed within the context of a common goal of European integration on refugee protection, asylum, and immigration issues.

The relationship, or relative absence thereof, between asylum and resettlement is perhaps one of the most confusing points for European policy making. There would naturally be knock-on effects for the European Union's emerging Common Asylum System if the Member States decide to pursue resettlement to a greater extent than is currently the case. These effects would be on the level of the definitions used to determine protection need in the two systems: procedures employed for status determination and integration measures. Indeed, the area of proactive integration policies may be one of the most fertile for a positive impact of resettlement on asylum and immigration generally in Europe. Through advance knowledge of who will be arriving, tailor-made integration programs can be established, starting with pre-departure orientation for the refugees and orientation information for the receiving communities. Such orientation can make expectations on all sides more realistic than might often be the case and provide a basis of motivation for the refugees to learn the language and become independent actors in their new communities.

Expanding resettlement in Europe could be useful in the EU asylum debates for the potential it offers to transform public, political, and expert debate on refugee protection. Information about who refugees are, where they are coming from, and media (among others) following their active integration as part of the new society are all facets of resettlement which could usefully be used by governments to promote positive, humanitarian approaches to protection - and should be used to apply to refugees arriving through asylum as well as those who are resettled. This is not to say that resettlement offers answers to the perceived problems with, or even crises in, the asylum systems in European states today. Nor should resettlement provide any government with a humanitarian alibi for reneging on its human rights obligations to grant asylum to those who have fled persecution in their state of origin. Rather, resettlement should coexist with asylum as two elements in a comprehensive international protection policy. While attention is on resettlement there may be room to deal with the diffi- culties presented by asylum and irregular entries, in a climate which is more beneficial to good policy making and supportive of refugees than that which prevails today.

As noted above, the European Commission and some Member States see a potential for resettlement to be strategically used to manage a greater number of legal arrivals to the EU Member States than at present. As the number of such arrivals, in 2003 , is less than 3,500 , it can be said with certainty that the development of resettlement capacity across the EU would facilitate the managed arrival of more refugees. If this was the sole supplementary strategic end, beyond the humanitarian motives and traditional goals of protection, durable solution, and solidarity, it could certainly be achieved. Success in this straightforward achievement would not affect or be affected by fluctuations in asylum-seeker numbers. However, the strategic goal implied by some is that the managed arrival of more refugees would reduce the number of people arriving to seek asylum.

There is no objective evidence that this see-saw hypothesis in terms of numbers (shifting from high asylum arrival and low numbers of resettlement places to high numbers of resettlement places and low asylum arrivals) could in fact be valid. Even in the days of more than 150,000 resettlement places per year, the U.S. never saw a drop in asylum-seeker numbers. It did, however, see a significant drop when it introduced asylum reform legislation in 1995. Perhaps one reason for which such reform legislation could be introduced was the fact of there being a large resettlement program (at that time with a ceiling of 112,000 places - and in fact a drop in the resettlement ceiling in 1996 to 90,000 places). ${ }^{13}$

One reason for which resettlement does not impact asylum-seeker numbers is that the pools of people drawn on for resettlement and those groups which are likely to seek asylum are quite different. Many people seeking asylum in western states come from complex situations of conflict and human rights abuses in major states (e.g., Russia) or places in which western governments hesitate to make clear-cut foreign policy choices backed by action. To resettle refugees, and more especially IDPs, from some of these situations would be to make a very decisive foreign policy statement. For example, the EU Member States are, in 2003-2004, seeing high levels of Russian asylum seekers. To enter Russian territory to select refugees for resettlement, and especially to select Chechens and others who claim to be suffering persecution now (as opposed to the U.S. resettlement activities in Russia which focus on past persecution), is quite unimaginable. What is more, in many of these cases, UNHCR is not present to protect and assist the populations, and so is not present to refer them for resettlement. In the cases of both Canada and the U.S., the lists of top ten countries of origin of asylum seekers see only 
one or two cases of overlap with the lists of countries of origin from which most resettlement is conducted.

Furthermore, those people who are in need of resettlement are most often those with no durable solution to their protection need, as opposed to people with an immediate and urgent protection need. Asylum systems in western states have generally developed in such a way that they seek very clear indications of immediate danger to the individual seeking refuge. The refugee in need of resettlement might not be able to present such indications to the satisfaction of an asylum adjudicator, but will have no long-term protection and security. As such, it may be necessary, for example, to resettle from states that might otherwise be considered "safe" for the purposes of asylum, but not for long-term protection of particular groups. This was the case, for example, when the U.S. decided to resettle some 10,000 Bosnians from Germany in order to avoid their (forced) return to a Bosnia that the US considered not yet safe following the Dayton Accords of 1995.

The see-saw hypothesis forms a major distraction in the construction of strategic and sensible resettlement policies. It is not impossible to imagine the EU Member States setting up resettlement programs with selection criteria so tainted by a desire to address smuggling and high asylum seeker arrivals from particular countries that they would actually be ineffective in addressing genuine resettlement needs. Nor is it impossible to envisage a resettlement program developed according to principles and criteria appropriate to an effective use of resettlement as a tool of international protection, which after a couple of years would be deemed a failure because of (unrelated) rises, or lack of changes, in asylum seeker arrivals. The linkage does not appear to be strategic for global refugee protection.

As far as the European context is concerned there is a need, indicated in the discussion above, to reinforce the fourth key point set out in the Introduction: resettlement is not part of an asylum system. Both resettlement and asylum are elements in an international refugee protection system. Since Tampere, the EU Member States and European Commission have discussed the development of a Common European Asylum System. Asylum is something all Member States have long offered to refugees arriving in their territory and asking for protection. It was a natural place to start. The European Commission set out by discussing resettlement as part of the emerging common asylum system. However, it is not clear that this is appropriate, semantically, politically, or as a matter of fact. For example, those EU Member States with resettlement programs generally conduct them separately from their asylum systems, as do all other resettlement countries.

Asylum and resettlement are not interchangeable either as a means of arrival for any particular individuals or as approaches to refugee protection. Rather, both asylum and resettlement are part of any full tool kit for dealing with international protection needs. I would suggest that Europe should both broaden its approach and clarify its terminology. Conducting resettlement as part of a Common European International Protection System, of which an asylum system would also be a part, would be a useful and strategic approach..$^{14}$ In this case, once agreements on resettlement as a policy approach and not a legal obligation were in place, the Member States and Commission would have room, within a Common European International Protection System, to recast the other elements, including asylum, which have a legal basis. European populations would thus get the distinct, and accurate, impression of a new management approach to refugee issues.

The crucial question is whether there is political will among a larger number of Member States to engage in resettlement. Before beginning any type of resettlement program the EU must be fully aware of the necessary level of resource commitment and the need to cultivate partners that would allow the program to function optimally. In getting to the point of perhaps starting a broader resettlement program, the EU Member States must also think strategically about more than just the impact of resettlement on refugee protection: they need to ask if developing this approach is good for European integration, or whether the discussion itself is potentially divisive. They need to ask if conducting resettlement would be positive for Europe's role as a humanitarian player in the refugee protection regime. Clearly, the EU's motives for and goals in doing resettlement would be important in defining its role in the global refugee protection regime, and therefore the European standing in global discussions on the strategic use of resettlement is important to consider.

\section{The Global Level: From Annual Tripartite Consultations to Convention Plus and Forum}

The progress towards discussion of the strategic use of resettlement at a global level has been going on for some six years. One point of interest about this progress is that it has in general involved only UNHCR and resettlement countries: countries in the regions of origin of refugees from or through which refugees are resettled have not been involved at all, NGOs have been involved on some occasions, and resettled refugees themselves have been involved only on one occasion (the conference on the integration of resettled refugees in Norrköping, Sweden, in 2001).

A 1994 UNHCR evaluation of resettlement highlighted several areas in which improvements could be made for better UNHCR operation of resettlement opportunities. ${ }^{15}$ Among the recommendations of the report (many of which, including this one, were acted upon) was the following: 
A multilateral forum for discussion and planning between UNHCR and major resettlement country governments and nongovernmental organizations must be established, to ensure a finetuning of complementary interests and strategic planning to address the evolving needs for resettlement. Governments should be encouraged to reflect on the current realities in terms of needs for resettlement and to seek to modify policies and procedures accordingly. Providing a forum for discussion of the wide range of innovative steps taken by individual governments in recent years could provide fertile ground for such crucial developments. ${ }^{16}$

This multilateral forum was created in the form of a Working Group on Resettlement. That group is made up of states and UNHCR. ${ }^{17}$ Coinciding with its meetings, Annual Tripartite Consultations, which involve states, UNHCR, and NGOs, are held.

One way in which existing resettlement countries felt they could usefully expand the role of resettlement was by expanding their own number through the addition of new resettlement countries. One development towards this end was the creation in 1997 of a Trust Fund. This fund applied the money which otherwise would have been spent on fifty resettlement places each in Norway, Denmark, and Sweden, with additional funds (not in lieu of resettlement places) from Finland and the U.S. The Fund financed initiatives to encourage emerging countries of resettlement and projects to enhance opportunities for individual and small groups being resettled and to improve the implementation of resettlement activities.

Part of the initial, Nordic thinking was that it would be more efficient to have some resettlement places in small, poorer countries which would be paid for by richer countries. However, in December 1998, UNHCR pointed out that this thinking was flawed, not least because the assumption that poorer countries would welcome the opportunity to develop refugee protection potential with funding from elsewhere proved inaccurate. ${ }^{18}$ It became apparent to UNHCR that the capacity for the development of new resettlement programs outside Europe was limited. While eight emerging countries of resettlement had joined the ranks by 2000, only three of them were still active in 2003 (Brazil, Chile, and Ireland). The UK joined this list in 2003 also, but it, like Ireland, was not stimulated by activities supported by the Trust Fund.

The U.S. contributions to the Trust Fund supported other initiatives, including the Norrköping conference on integration of resettled refugees, and the two Handbooks, one on resettlement programs and admission to those programs and one on integration. ${ }^{19}$

Meanwhile, the Global Consultations process led to an Agenda for Protection, which addresses both the burdensharing aspects of resettlement and the need for a stronger focus on durable solutions. ${ }^{20}$ In order to build on this Agenda for Protection, the High Commissioner called for the development of special agreements to complement the Convention, which he called "Convention Plus." An arena called the Forum was established for the discussion of particular subjects of interest. The Forum's first meeting, on 27 June 2003, focused on resettlement. At this meeting, the Canadian delegation tabled a discussion paper, "Resettlement and Convention Plus Initiatives," suggesting that resettlement, in the context of an approach to all durable solutions, could be an ideal area for partnership agreements between states, UNHCR, and NGOs. This paper had been in development in the Working Group on Resettlement, under Canadian chairmanship, after the initiative to discuss the strategic use of resettlement was put forward by Australia. Drawing largely on its own resettlement program for context, the Canadian delegation suggested that it could, together with UNHCR, lead further discussions beyond this initial meeting. The Canadian document also drew attention to important points which are key to contemporary discussion of resettlement, including:

- Solutions are only durable when they result in a refugee having secure legal status in the country providing the durable solution.

- As an administrative decision, resettlement can be a timely and cost-efficient durable solution.

- The inclusion of protection-based criteria that go beyond the 1951 Convention would help to make resettlement a more flexible tool.

The three goals of resettlement as a durable solution, a protection tool, and a burden-sharing instrument remain paramount. As noted above, resettlement programs are nonetheless often shaped by other functions.

It should be noted that motives, goals, and functions are quite different facets of any policy. In the case of resettlement, the motive is humanitarian; the goals are protection, a durable solution, and burden sharing; and the function can be any of the strategic uses to which states put resettlement, e.g., to support their foreign policy aims, to show solidarity with domestic ethnic communities, or, potentially, to counterbalance their asylum systems by offering a means for managed and organized arrival for refugees as well as the irregular entry which the seeking of asylum often necessitates.

The UNHCR Working Group on Resettlement, in its paper The Strategic Use of Resettlement, ${ }^{21}$ noted that the managed and orderly arrival of persons in need of international protection could result from resettlement. The Commission's Communication of 3 June $2003^{22}$ indicates that EU Member States might indeed find the political will to pursue resettlement as a way to provide for "managed and 
orderly arrivals of persons in need of international protection." This could potentially be an intended additional function of resettlement for EU states. However, the motive of resettlement should remain humanitarian. It is a normative contention: but converting a function (a desired or intended consequence) of a policy into a motive for operating that policy is quite dangerous, as it leads to the potential undermining of a path which originated in genuinely altruistic and noble motives.

The concern to manage the arrival of refugees can be, and is being, interpreted as a desire to limit asylum seeker admissions. The Canadian Council for Refugees (CCR), in response to the Working Group paper The Strategic Use of Resettlement, stated that "Resettlement... is not an 'orderly' alternative to asylum." ${ }^{23}$ However, managing the arrivals of more refugees successfully, and using resettlement strategically to achieve that goal, should not have to mean that states seek to reduce or prevent asylum seeker arrivals.

Reactions such as CCR's are in large part inspired by the European debate on resettlement as a response to high asylum seeker numbers, as described above, as well as by Australian practice. In order to avoid such reactions, it would be useful if EU Member State governments, the European Commission, and other resettlement countries which seek to stimulate greater participation in resettlement by the EU states could make clear that their intention in promoting this potential function of resettlement is not to suggest that the EU could or would close down, or further limit, access to asylum procedures. Although the European Commission has frequently written that asylum must remain open, both its, and Member States', representatives send mixed signals as the UK "vision" paper and the discussion it provoked demonstrate.

Although resettlement could not accomplish the function of significantly reducing asylum seeker numbers, it could certainly be used as a response to the indicator, which high arrival numbers give, that there is a refugee crisis going on somewhere. Then EU Member States could engage actively in selecting, resettling, and protecting refugees, thereby allowing or persuading states in the region of origin to provide protection to more people, knowing onward, managed movement is available. Such a use of resettlement would be strategic in offering protection, showing solidarity, and bolstering the EU's reputation as a humanitarian actor.

\section{Conclusions}

The strategic use of resettlement is a multi-faceted idea. European states would have several strategic reasons for engaging in resettlement other than any potential or desired impact on asylum seeker arrival statistics. They are also the most likely new resettlement countries, the ones that have the potential to create the most effective new, large-scale resettlement programs. Collective strategic engagement in resettlement could significantly strengthen the EU harmonization process. It would also be strategic for the EU to engage in resettlement because the image of resettled refugees is generally more positive than that of asylum seekers, but also often has a "knock-on" effect, meaning that the public gets more information and understands more about the situations from which both resettled refugees and asylum seekers have fled.

As a matter of strategy, EU Member States should view resettlement as part of a comprehensive approach to protection, which includes other durable solutions and is linked to the EU's external relations as well as its overall immigration and asylum policy development.

These benefits of the development of broader resettlement programs can be much more important in demonstrating that governments are managing the refugee protection issue well than any impact those programs may or may not have on actual numbers of arrivals.

For Europe, and therefore for the global refugee regime, to engage strategically in resettlement, the distinction between motive, goals, and supplementary functions needs to be established. Resettlement needs to be clearly distinguished from asylum. The debate on resettlement places replacing asylum arrivals numerically should be closed. Any potential impact on asylum seeker numbers could better be handled as an unintended consequence, rather than as a direct desire without which resettlement will be viewed as ineffective. The perception of resettled refugees, through appropriate explanations of policy and the people affected in the media, for example, should be managed in such a way that one of the knock-on effects between resettlement and asylum seeking is an improved image for all refugees as people in need of protection. In this way, the strategic use of resettlement could change the face of protection, and benefit all refugees and all states engaging in the full range of protection tools.

\section{Notes}

1. The European Commission contracted the Migration Policy Institute to conduct the Study on the feasibility of setting up resettlement schemes in EU Member States or at the EU level, against the background of the Common European Asylum System and the goal of a Common Asylum Procedure. This study was completed in September 2003 and is available at $<$ http://www.europa.eu.int/comm/justice_home/doc_centre/ asylum/studies/docs/resettlement-study-full_2003_en.pdf $>$. The U.S. Department of State contracted Professor David Martin to conduct a study of its refugee admissions program. The report of the study, tentatively entitled The U.S. Refugee Admissions Program: Reforms for a New Era of Refugee Resettlement, is likely to be released in early 2004 . 
2. For discussion of this point, see Gregor Noll and Joanne van Selm, Rediscovering Resettlement (MPI Insight No.3, December 2003), http://www.migrationpolicy.org/insight/Insight_3_12-2003.pdf.

3. The programs are all described at length in the feasibility study cited above at note 1 .

4. The UK's program started in April 2003. While the first selection missions have taken place, no refugees have arrived at the time of writing.

5. Argentina has been removed from the list of emerging resettlement countries.

6. The programs in Benin and Burkina Faso have been suspended and are under review.

7. Spain has been removed from the emerging resettlement countries list, as there had been no arrivals for three years, and there was no fixed quota, just an ad hoc policy.

8. Resettlement countries attribute numbers to their resettlement programs. The U.S. operates a ceiling, i.e., an upper limit. The logic to this is that there is a maximum number for planning, but a conscious desire to say that there might not be that many refugees in need of resettlement in any given year. In fact, the arrivals have always fallen short of the ceiling, and often by several thousand (by 30,000-45,000 in 2002 and 2003), and this has caused public and political dismay. The European states that conduct resettlement use quotas and the aim then is to meet that number but not exceed it. Sweden and Finland generally fill their quotas; the Netherlands has fallen short for several years now. Canada uses targets, allowing them to fall short or exceed the set number by a reasonable margin and still be on target. The feasibility study on resettlement for the European Commission suggests a target band approach for the European Union, with a bidding process for individual Member State targets within the band that is set for the whole.

9. In that three-year period, 167,814 applications for resettlement were received, and 26,758 for asylum.

10. The proportions are smallest for Finland at about three asylum seekers for every resettled refugee. Finland purposefully resettles refugees in order to increase its role in refugee protection in the EU context, since its asylum-seeker arrivals are proportionally small.

11. Besides the UK and Ireland as mentioned above, the German ruling coalition parties (SDP and Greens) included the development of a 500-person resettlement program in their coalition agreement in 2002.

12. Commission of the European Communities, Communication from the Commission to the Council and the European Parliament, Towards more accessible, equitable and managed asylum systems, Brussels, 3.6.2003 COM(2003) 315 final. The UK proposals were widely known as "A New Vision for Refugee Policy" and were first leaked in the Guardian newspaper on 5 February 2003.

13. Resettlement ceiling, arrivals, and asylum arrivals in the U.S. at the time of the 1995 Asylum Reform Act and its impact were:

\begin{tabular}{|c|c|c|c|}
\hline & $\begin{array}{c}\text { Resettlement } \\
\text { Ceiling }\end{array}$ & $\begin{array}{c}\text { Resettlement } \\
\text { Arrivals }\end{array}$ & $\begin{array}{c}\text { Asylum } \\
\text { Arrivals }\end{array}$ \\
\hline 1995 & 112,000 & 99,490 & 148,695 \\
\hline 1996 & 90,000 & 75,693 & 107,130 \\
\hline 1997 & 78,000 & 70,085 & 52,217 \\
\hline
\end{tabular}

14. The suggestion of a Common European International Protection System, incorporating a Common Asylum Policy, a Common Resettlement Program, an EU Temporary Protection approach, and EU humanitarian assistance and capacity building programs, is set out at length in the feasibility study on Resettlement (see note 1, above) and in "The EU as a Global Player in the Refugee Protection Regime," Working Paper No. 35, Academy for Migration Studies in Denmark (AMID), forthcoming at http://www.amid.dk/pub/index.html.

15. John Fredriksson and Christine Mougne, Resettlement in the 1990s: a review of policy and practice, UNHCR EVAL/RES/14, 1994.

16. Ibid., 9 (emphasis added).

17. The European Commission and IOM are also involved in the Working Group. It reports to the UNHCR Executive Committee.

18. Danish Immigration Service, "Evaluation of UNHCR's Trust Fund for Enhancing Resettlement Activities" (undated mimeo with the author of this article).

19. UNHCR, Division of International Protection, Resettlement Handbook (Geneva, July 1997; revised July 2002) and UNHCR, Refugee Resettlement: An International Handbook to Guide Reception and Integration (September 2002).

20. Goals 3 and 5 in the Agenda for Protection, http://www. unhcr.ch/cgi-bin/texis/vtx/home/opendoc.pdf?tbl=EXCO M\&id=3d3e61b84. See also EC/GC/02/7 Strengthening and expanding resettlement today: dilemmas, challenges and opportunities, for Global Consultations on International Protection 4th Meeting, Third Track.

21. The Strategic Use of Resettlement: A Discussion Paper Prepared by the Working Group on Resettlement WGR/03/04.Rev3 (3 June 2003).

22. Commission of the European Communities, Towards more accessible, equitable and managed asylum systems.

23. Canadian Council for Refugees, A Working Paper on the Strategic Use of Resettlement (June 2003).

Joanne van Selm is Senior Policy Analyst, Migration Policy Institute, Washington, D.C., and Senior Researcher, Institute for Migration and Ethnic Studies, University of Amsterdam. She also is President of the International Association for the Study of Forced Migration and Co-editor of the Journal of Refugee Studies. 